\title{
A Network Text Analysis of Fight Club
}

\author{
Starling Hunter \\ Tepper School of Business, Carnegie Mellon University Qatar, Doha, Qatar \\ Saba Singh \\ Tepper School of Business, Carnegie Mellon University Qatar, Doha, Qatar
}

\begin{abstract}
Network Text Analysis (NTA) involves the creation of networks of words and/or concepts from linguistic data. Its key insight is that the position of words and concepts in a text network provides vital clues to the central and underlying themes of the text as a whole. Recent research has used an inductive or bottomup approach to the question of theme extraction. In this paper we take a top-down or deductive approach in that we first establish prior expectations as to the key themes to be found in the text. We then compare and contrast the results of our network analysis with the results of literary and cultural analyses of the film Fight $C l u b$ as reported in over four dozen other peer-reviewed publications. While our results are remarkably consistent with and complementary to results in those studies, our analysis permits something the others do not - an analytical framework for relating those underlying and central themes to one another.
\end{abstract}

Index Terms - network text analysis, social network analysis, Fight Club, Chuck Palahniuk, film criticism, semantic network

\section{INTRODUCTION}

Network text analysis (NTA) involves the identification of important lexical relationships among words and concepts in a text and their subsequent representation in the form of a network or map (Popping, 2000). Like other methods of content analysis, NTA operates on the assumption that the structure of a text encodes its meaning (Fischer-Starcke, 2009). Its major point of differentiation-perhaps its defining difference-is how it defines that structure. The most widely employed methods of content analysis - ones employed in corpus linguistics, corpus stylistics, and computational linguistics - establish structure from the frequency with which certain key words appear in the text and/or the frequency with which those words co-occur (Stubbs, 2005; Popping \& Roberts, 1997). Several approaches to NTA have been developed in the last five decades. These include mental models (Collins \& Loftus, 1975), knowledge graphs (Bakker, 1987), concept maps (Novak ,1990), map comparison/ analysis (Carley \& Palmquist, 1992), word network analysis (Danowksi, 1993), semantic networks (Sowa, 1992), functional depiction (Popping \& Roberts, 1997), sociocognitive networks (Carley, 1997; Diesner, 2013), semantic grammars (Roberts, 1997), centering resonance analysis (Corman, Kuhn, McPhee, \& Dooley, 2002), semantic webs (van Atteveldt, Kleinnijenhuis, \& Ruigrok, 2008), and morpho-etymological networks (Hunter, 2014a, 2014b). While each of these methods defines textual structure in a different manner, they all share two explicit assumptions. The first is that otherwise invisible properties of texts can be identified when words and concepts are represented and understood as networks (Diesner \& Carley, 2005). The second is that a text's key themes are associated with the words and concepts that occupy the most influential positions in the network. Despite sharing these foundational assumptions, approaches to NTA vary along at least two key dimensions. The first concerns the specific lexical or conceptual item to be studied, as well as the nature of the relationship that joins them. Variation in the choice of item and relationship is what produces variation in the definition of the text structure. A second concerns the level of automation or computer-support (Diesner \& Carley, 2005). Despite these differences, the four fundamental steps in all network text analyses are the same (Diesner, 2012). They are the selection of certain words or concepts in a text for subsequent analysis, the abstraction of these words or concepts to higher-level conceptual categories, the identification of a relationship that can be used to connect the conceptual categories to one another, thereby forming a network, and the extraction of meaning and key themes from the most influential nodes (concepts) in that network.

Several recent studies have focused on the latter of these four stages, i.e. the extraction of key themes. These include network text analyses of screenplays (Hunter, 2014a), mission statements (Grbic, Hafferty, \& Hafferty, 2013), newspaper articles (Tambayong \& Carley, 2013), presidential inaugural addresses (Light, 2014; Chung \& Park, 2010), and extremist propaganda (Morris, 2014). Despite the wide variety of texts and research questions, all of these studies derived the themes inductively, i.e. from the bottom-up. That is to say, the analysts approached the texts without strong prior assumptions or expectations as to what the themes would or should be. Typical of the bottom-up approach is Hunter (2014a) who created text networks for seven recent, Academy-Award winning, best original screenplays—Little Miss Sunshine, Juno, Milk, The Hurt Locker, The King's Speech, Midnight in Paris, and Django Unchained. In five of the seven networks he reported that key themes of the story were clearly associated with the most influential nodes in the network. For example, in the text network of the Iraq-war-themed The Hurt Locker he found the following words 
and concepts associated with the most influential nodes in the network-army-issue, body armor, fireball, gunfire, gunshot, HUMVEE, IED (improvised explosive device), machine gun, shell-shocked, suicide bomber, and USA. In the screenplay for Milk, biopic about the openly-gay mayor of San Francisco who was infamously assassinated by a fellow politician, words and concepts associated with the most influential nodes in the network included AIDS, elected official, public office, city council, city hall, city-wide, civil rights, town hall, manslaughter, congressman, human rights, right wing, nationwide, and statewide. Similarly, while Grbic, Hafferty, \& Hafferty (2013) hypothesized that the mission statements of public and private medical schools, as well as those of social-mission vs. research-focused medical schools, would have different text networks, they did not specify a priori the content of those differences or the network positions of key differentiating concepts. The current study is the first of which we are aware that takes a deductive or top-down approach. That is to say, unlike the aforementioned studies, we first develop strong priors about the key themes that should be found in our text, the screenplay of Fight Club (Uhls \& Palahniuk, 2000). Those expectations are developed by a review of over four dozen published, peer-reviewed journal articles that analyzed the movie Fight Club and/or the novel from which the screenplay was adapted (Palahniuk, 1996). We then perform a network text analysis on the screenplay and see whether the results match our expectations.

\section{TALKING ABOUT Fight Club}

Fight Club was the first published novel by American Chuck Palahniuk and it appeared in 1996. In 1999 a film by the same name was released starring Brad Pitt as the antagonist, Tyler Durden, and Edward Norton Jr. as the unnamed Narrator and protagonist. According to director David Fincher, Norton's unnamed character is an "everyman" who we discover is very discontented, even "emasculated" by his white collar job and consumerist lifestyle (Smith, 1999). To escape these doldrums, he eventually forms a club with a soap-maker partner (Tyler Durden) where men fight recreationally. The novel earned moderate critical acclaim garnering its author both the Pacific Northwest Booksellers Association Award and the Oregon Book Award for Best Novel in 1997. The film adaptation initially disappointed at the box office, earning only $\$ 37$ million during its U.S. and Canadian theatrical run versus a production budget of $\$ 63$ million. The film did eventually turn a profit because foreign box office receipts pushed the total to just over $\$ 100$ million (Box Office Mojo, 2014). But despite the initially poor box office showing, imagery and dialog from the film leapt immediately into the mainstream of popular culture. Perhaps the most famous - or infamous-line from the film concerns the clubs rules - "The first rule of fight club is you do not talk about fight club."

And if the measure of performance of the film and novel was the degree to which people have ignored that rule, then both the novel and film - but especially the latter-have been an enormous success. Debates began in earnest shortly after the film's world premiere at the Venice Film Festival and continued unabated through its US theatrical release. The film also became somewhat notorious for its influence in the popular culture with many fight clubs being formed around the US (Crowdus, 2000). Academics and culture critics have done their fair share of talking about Fight Club too. Perhaps as a result of its cultural impacts of the film, critics of popular culture and the arts were among the first in academia to analyze both Fight Club. Our research identified over 100 articles about the film and/or novel that were published in peer-reviewed academic journals between 1999 and 2014. Of those written in the humanities, subject matter of the journals includes literature, film studies, gender, religion, popular culture, social theory, psychology, postmodern studies, Gothic studies, the sociology of sport, and race, media and culture, communication, and trauma.

\section{Methods \& DATA}

\section{A. Identifying the Key Themes}

The first task in the analysis was to determine the major themes of the novel and film, as articulated by academic analysts and critics. The authors met four times to make these determinations. The first meeting concerned reconciling our selection of the peer-reviewed journal articles that would form the basis of our subsequent analysis. Prior to this meeting each author separately used the Google Scholar search engine to generate a list of citations using search terms that include the phrase "Fight Club" plus the name of either the film's director (David Fincher), the screenplay's author (Jim Uhls), or the author of the novel (Chuck Palahnuik). The first author separately saved all citations to journal articles to his own Google Scholar library. The second author saved all relevant citations directly to her hard drive. When we met we discovered that the major differences in our selection concerned three issues: whether or not to include book or movie reviews that appeared in peer-reviewed journals (we decided not to); whether and how to treat articles that did not have abstracts; and whether and how to accommodate articles that analyzed the film or book from the standpoint of film or narrative theory. Concerning the second issue, we decided to use only the text that appeared in the first paragraph of article. In those cases where it was not possible to obtain a copy of the paper, the article was excluded from consideration. Concerning the latter, we opted to eliminate all articles that were not expressly cultural or social analyses or critiques of the film. At the conclusion of this meeting we ended up with the 52 peer-reviewed articles listed in the Appendix. As shown in Table 1, several major and inter-related themes are evident in the academic literature over the fifteen years since the theatrical release of Fight Club and the nearly twenty years since the novel's publication. 
At the second meeting the authors reconciled the first version of the categories of themes that were to be later used to code statements contained in the abstracts or lead paragraphs. Prior to the meeting each author separately reviewed different halves of the aforementioned 52 abstracts or lead paragraphs and created their own lists of major themes that were present therein. Specifically, each author highlighted key phrases and words used to describe the protagonist, the antagonist, the film, the novel, and/or the major themes of those works. Examples include phrases like "the films Fight $C l u b \ldots$ and Memento revolve around similar themes...the individual's struggle with late capitalism in order to establish identity in a de-centered world" (Kravitz, 2004) and "...the Fight Club ethic...is rooted in guerilla-type resistance to commodity culture" (Del Gizzo, 2008). Each author separately abstracted all relevant terms in these statements and converted them into nouns, e.g. capitalism, identity, guerilla, resistance, commodification. When we met, we discussed the overlap and the differences in the two lists which contained a total of 41 such nouns. After agreeing on common names for highly similar terms the list was reduced to 26 nouns.

At the third and fourth meetings we jointly reviewed every statement that either author had previously identified and re-assigned each one to one or more relevant noun-themes. When and where it seemed appropriate, we reduced the number of noun-themes to create conceptually broader categories. Of course, this often necessitated re-naming of existing noun-themes. After several iterations we ended up with the following 12 noun-themes which, order alphabetically, are AGENCY, ANARCHISM, BODY, CAPITALISM, GENDER, IDENTITY, PATHOS, POWER, PSYCHOPATHOLOGY, RACE/CULTURE, SEX, and VIOLENCE. These appear in the first column of Table 1. The second column contains the noun forms of typical terms abstracted from the relevant phrases that we found in the abstracts and first paragraphs. The third column contains examples of the actual phrases contained in those abstracts and paragraphs.

The third and final step of the thematic analysis was to identify the most dominant themes in the literature. Rather than rely on the frequency with which the themes appear, we created a concept map of authors and themes. The result is shown in Fig. 1 where squares represent themes and circles represent authors. When a circle (author) appears between two squares (themes) it indicates that the author mentioned both of these themes in the abstract or first paragraph. For example, in the upper left corner we see that Slade (2011) is represented by a circle that is located between the themes GENDER and VIOLENCE whereas Burgess (2012) appears between the squares representing BODY and VIOLENCE. A view of the map as a whole reveals that the themes can be ordered from greatest number of links to the lowest as follows: GENDER, IDENTITY, CAPITAL, POWER and PSYCHOPATHOLOGY (tied), ANARCHISM, SEX and VIOLENCE (tied), PATHOS, RACE/CULTURE, BODY, and AGENCY. It is this ranking that we subsequently use to test whether the position of concepts within the text network can accurately ascertain key themes of the story as found in the adapted screenplay of Fight Club (Uhls \& Palahniuk, 2000).

TABLE I.

KEY THEMES IN FIGHT CLUB

\begin{tabular}{|c|c|c|}
\hline Theme & Terms & Example Phrases \\
\hline AGENCY & self-help & $\begin{array}{l}\text { - "it is...rebelling against a consumerist culture that dissolves the bonds of male sociality and puts } \\
\text { into place an enervating notion of male identity and agency" (Giroux, 2001) }\end{array}$ \\
\hline BODY & body, bodies & $\begin{array}{l}\text { - "two identities inhabiting the same body" (Ta, 2006) } \\
\text { - "the splitting of both the psyche and the body" (Ruddell, 2007) } \\
\text { - "the film's retrograde version of a violent masculinity rooted in the male body" (Robinson, } \\
\text { 2011). }\end{array}$ \\
\hline CAPITAL & $\begin{array}{l}\text { capitalism, } \\
\text { consumerism, } \\
\text { globalization }\end{array}$ & $\begin{array}{l}\text { - "Fight Club appears to offer a critique of late capitalist society" (Giroux, 2001) } \\
\text { - "to reevaluate Fight Club's representation of capitalism, to develop a value-theoretic account of } \\
\text { trash" (Henderson, 2011) } \\
\text { - "...its logic implies that action is required against the effects of globalized capitalism..." } \\
\text { (Jordan, 2002) }\end{array}$ \\
\hline ANARCHISM & $\begin{array}{l}\text { anarchism, } \\
\text { dystopia, nihilism, } \\
\text { post-modernism }\end{array}$ & $\begin{array}{l}\text { - "most people in the world... are attracted to dystopic stories about the end of capitalism" } \\
\text { (McCullough, 2005) } \\
\text { - "The characters in Fight Club avoid nihilism by acquiescing to love without fixed definition" } \\
\text { (Aparicio, 2013) } \\
\text { - "Fight Club tells the story of an unnamed narrator and the nihilistic Tyler Durden (Rehling, } \\
\text { 2001). }\end{array}$ \\
\hline GENDER & $\begin{array}{l}\text { gender, } \\
\text { masculinity, } \\
\text { feminity, } \\
\text { paternalism, } \\
\text { virility }\end{array}$ & $\begin{array}{l}\text { - "Fight Club tends to emphasize its relevance for the study of contemporary representations of } \\
\text { gender and masculinity (Lizardo, 2007) } \\
\text { - "Fight Club has provoked a great deal of theorizing about gender..." (Robinson, 2011) } \\
\text { - "Fight Club was one of many contemporary films depicting masculinity in crisis..." (Rehling, } \\
\text { 2001) } \\
\text { - "Race and the Construction of White Masculinity in David Fincher's Fight Club" (Locke, 2014) } \\
\text { - "Fight Club as a foil against which we try to pin larger issues of masculinity and urban life" } \\
\text { (Craine \& Aitken, 2004) }\end{array}$ \\
\hline
\end{tabular}




\begin{tabular}{|c|c|c|}
\hline $\begin{array}{l}\text { IDENTITY- } \\
\text { INDIVIDUAL }\end{array}$ & $\begin{array}{l}\text { identity, } \\
\text { identification } \\
\text { doppleganger } \\
\text { double } \\
\text { self-consciousness } \\
\text { self-help }\end{array}$ & $\begin{array}{l}\text { - "Fight Club's narrative logic and its complex, imaginative imbrication of identity and historical } \\
\text { self-consciousness (Friday, 2003) } \\
\text { - "Chuck Palahniuk's Fight Club (1997) addresses the identity crisis of white, heterosexual, } \\
\text { American men..." (Boon, 2003) } \\
\text { - "Fight Club reflects the protagonist's inability to establish an identity for himself" (Gunn \& } \\
\text { Frentz, 2010) } \\
\text { - “... an extraordinary film that explores an often-violent intersection between the conditions of } \\
\text { late-capitalist consumer society and contemporary masculine identities" (Iocco, 2003) } \\
\text { - “...(he) is revealed as an individual who suffers from the actual medical disability, Dissociative } \\
\text { Identity Disorder. (Ta, 2006) }\end{array}$ \\
\hline $\begin{array}{l}\text { IDENTITY- } \\
\text { SOCIAL }\end{array}$ & $\begin{array}{l}\text { male bonding } \\
\text { homosocial relations } \\
\text { class }\end{array}$ & $\begin{array}{l}\text { - "the homoerotic attraction that lies just beneath the film's celebration of homosocial bonding" } \\
\text { (Westerfelhaus \& Brookey, 2004) } \\
\text { - "identifying himself as a product of consumer society" (Pettus, 2000) } \\
\text { - "(the) protagonist will attempt to use his body to escape the control of society and re-establish } \\
\text { his identity and will" (Kravitz, 2004) } \\
\text { - "Through examining examples of "fighting" in Fight Club, the article will discuss male bonding } \\
\text { through homosocial (and somewhat homophobic) relations" (Iocco, 2003) } \\
\text { - "Fight Club provided a point of identification for its embattled white, middle-class, target } \\
\text { audience" (Bedford, 2011) }\end{array}$ \\
\hline PATHOS & $\begin{array}{l}\text { anxiety, } \\
\text { crisis, } \\
\text { pain, } \\
\text { suffering, } \\
\text { distrust, } \\
\text { malaise, } \\
\text { disaffection, } \\
\text { Gothic }\end{array}$ & $\begin{array}{l}\text { - "Palahniuk dramatizes a situation in which contemporary culture is made responsible for a crisis } \\
\text { in masculine identity" (Jordan, 2002) } \\
\text { - "These people experience the real physical and psychological pain of approaching death where } \\
\text { the protagonist does not..." (Schultz, 2011) } \\
\text { - "Fight Club reworks the Gothic topos of the Doppelgänger in a twentieth-century American } \\
\text { urban context (Stirling, 2004) } \\
\text { - "In his attempt to heal himself of his malaise, (the narrator) encounters Tyler Durden...who } \\
\text { seduces (him) into co-founding Fight Club" (Ta, 2006). }\end{array}$ \\
\hline POWER & $\begin{array}{l}\text { power, hegemony, } \\
\text { domination, } \\
\text { exploitation, } \\
\text { victimization, } \\
\text { resistance, } \\
\text { persecution, fascism }\end{array}$ & $\begin{array}{l}\text { - “...in Palahniuk's Fight Club, the narrator is in a certain crisis of manhood as a result of his } \\
\text { contradictory experiences of power under the impositions of hegemonic masculinity" (Vafa \& } \\
\text { Talif, 2011) } \\
\text { - “...the film recommends violence as a solution to a perceived crisis in the lives of a generation } \\
\text { of American men who lack the power to find meaning in the wastes of consumer culture" } \\
\text { (Robinson, 2011) } \\
\text { - "...(the club) rebels against a seemingly impersonal and feminized dominant culture by blowing } \\
\text { up that very world...(Ta, 2006) } \\
\text { - "All three movies exhibit a sense of victimisation, persecution and distrust..." (Yeo, 2014) }\end{array}$ \\
\hline $\begin{array}{l}\text { PSYCHO- } \\
\text { PATHOLOGY }\end{array}$ & $\begin{array}{l}\text { mental health, } \\
\text { psychosis, } \\
\text { schizophrenia, } \\
\text { paranoia, narcissism, } \\
\text { psychopathology, } \\
\text { perversity, } \\
\text { sado-masochism }\end{array}$ & $\begin{array}{l}\text { - "... we argue that the film Fight Club can be understood as a mediation of a larger, cultural } \\
\text { psychosis." (Gunn \& Frentz, 2010) } \\
\text { - "Fight Club well represents the violent effects of capitalism on psychic structure ... (and)... the } \\
\text { damaging effects of capitalism on the male psyche." (Layton, 2011) } \\
\text { - "...the narrative fits perfectly with the psychopathology model of cult recruitment" (Lockwood, } \\
\text { 2008) } \\
\text { - "...the Art/Politics of White Male Victimization and Reflexive Sadomasochism" (Kusz, 2002) } \\
\text { - "...the Gothic movie renders its protagonist, the viewer, schizophrenic and paranoid as well" } \\
\text { (Yeo, 2014) } \\
\text { - "It was argued that Fincher's version suffers from the same sense of schizophrenia as its } \\
\text { protagonist." (Bishop, 2006) }\end{array}$ \\
\hline $\begin{array}{l}\text { RACE- } \\
\text { CULTURE }\end{array}$ & $\begin{array}{l}\text { white, western, } \\
\text { Asian, race, racism, }\end{array}$ & $\begin{array}{l}\text { - "Offering a critical interrogation of white masculinity within David Fincher's Fight Club" (King, } \\
\text { 2009) } \\
\text { - "This white, male, white-collar, and well-paid protagonist..." (Schultz, 2011) } \\
\text { - "Palahniuk's Fight Club (1997) addresses the identity crisis of white, heterosexual, American } \\
\text { men..." (Boon, 2003) } \\
\text { - "...issues raised in Fight Club about fighting are...powerfully relevant in white western } \\
\text { industrialised context" (Iocco, 2003) }\end{array}$ \\
\hline SEX & $\begin{array}{l}\text { sexuality, } \\
\text { homosexuality, } \\
\text { homophobia, } \\
\text { homoeroticism, } \\
\text { heterosexuality, } \\
\text { love }\end{array}$ & $\begin{array}{l}\text { - "...the film's narrative is structured around a quasi-religious ritual that reaffirms heterosexuality } \\
\text { at the expense of homosexuality..." (Westerfelhaus \& Brookey, 2004) } \\
\text { - "Fight Club is clearly one of the films that are most often addressed by researchers and cultural critics wanting } \\
\text { to probe the relationship between sexuality, politics and popular culture" (Lindgren, 2011) } \\
\text { - "Fight Club's DVD "extra text" dissuades the viewer from acknowledging the film's homoerotic } \\
\text { elements as representing homosexual experience" (Brookey \&Westefelhaus, 2002) }\end{array}$ \\
\hline VIOLENCE & $\begin{array}{l}\text { violence, } \\
\text { aggression, } \\
\text { militarization, } \\
\text { terror, terrorism }\end{array}$ & $\begin{array}{l}\text { - "As a response, the narrator sets out a nostalgic backlash to grapple with the outlets of the } \\
\text { crisis-buried feelings, homophobia and aggression" (Vafa \& Talif, 2011) } \\
\text { - ".... divided subject that seeks release in brute, regressive masculinity" (Ta, 2006) } \\
\text { - "....it is about a man with multiple personality disorder who tries to fight his disillusionment by } \\
\text { turning to violence and anarchy" (Bishop, 2006) } \\
\text { - "... academics debated whether the film recommends violence as a solution to a perceived crisis } \\
\text { in the lives of a generation of American men..." (Robinson, 2011) } \\
\text { - "Initially panned by many critics for its violent content, David Fincher's Fight Club may seem } \\
\text { like the most unlikely film to incorporate the tenants of Zen Buddhism" (Reed, 2007). }\end{array}$ \\
\hline
\end{tabular}




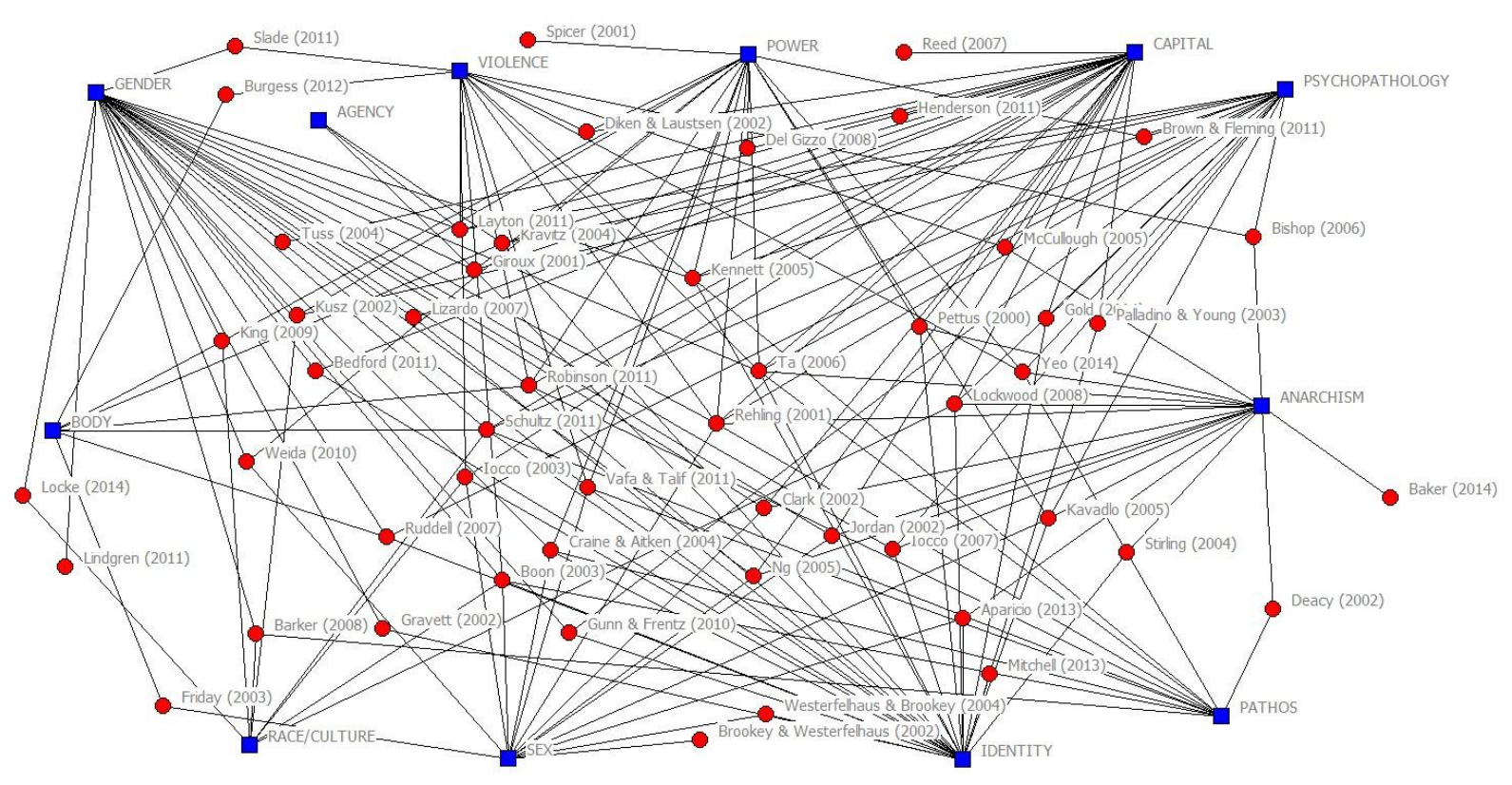

Figure 1. A concept map of authors vs. themes mentioned in fifty-two academic journal articles about Fight Club

\section{B. The Selection of Words for Subsequent Analysis}

Diesner (2012) identified nearly 20 distinct approaches for constructing text networks and compared and contrasted them along several dimensions. In this study we apply a novel method not included in Diesner's review-the morphoetymological approach recently developed by Hunter \& Smith (Hunter \& Smith, 2013; Hunter, 2014a; Hunter, 2014b). In that approach, a network is constructed from morphological and etymological relationships among words in the text. A hallmark of that approach concerns its selection rule - the first stage of a network text analysis. In short, only multimorphemic compounds (MMCs) are retained for analysis. MMCs include abbreviations, acronyms, blend-words or portmanteau, selected clipped words, several varieties of compound words, examples of which are shown in Table 2.

TABLE II.

SELECTED EXAMPLES OF TEN TYPES OF MULTI-MORPHEMIC COMPOUNDS FOUND IN FIGHT CLUB

\begin{tabular}{|l|l|}
\hline Type & Selected Multi-Morphemic Compounds in Fight Club \\
\hline Abbreviations, Acronyms & $\begin{array}{l}\text { TFM (task force man), SE (south-east), AR (automatic rifle), yuppie (young urban } \\
\text { professional), IBM (international business machine) }\end{array}$ \\
\hline Blend Words & laundromat (laundry + automatic) \\
\hline Clipped Words & Microsoft (microcomputer + software), email, cybernetting \\
\hline Closed Compounds & Jackhammer, headquarters, handgun, uppercut, airport, breadcrumbs \\
\hline Conversion & Star-sixty-nined \\
\hline Copulative & Walkie-talkie \\
\hline Hyphenated Compounds & self-destruction, born-again, Psycho-boy, \\
\hline Multi-word Compounds & Out-of-court, cry-for-help, death-warmed-over, merry-go-round \\
\hline Open Compounds & Office park, orange juice, phone number, rock star, army surplus \\
\hline Prefixed & Overhanging, overlap, overturned, underground, understand \\
\hline
\end{tabular}

We identified the MMCs in this study with the use of the "Concept List" routine in the CASOS Institute's Automap software program (Carley, Columbus, \& Landwehr, 2013). That routine output lists each unique word appearing in the text, along with each word's frequency of occurrence. After eliminating stop-words known not to be MMCs, and including differences attributable to inflection, pluralization, and capitalization, there were approximately 1920 unique words in the list appearing almost 24,000 times in text of the screenplay. Each author read the entire list individually and identified the MMCs contained therein. After reconciling their coding we ended up with a list of $316 \mathrm{MMCs}$, about $1 / 6^{\text {th }}$ of the number of unique words. Excluded from consideration were numbers that were spelled out, e.g. eighteen. However, we retained numbers that were part of compounds, e.g. three-story, as well as the adjectival forms of numbers when they appeared as part of an MMC, e.g. second-hand. We did not retain neoclassical compounds, e.g. photograph or telephone but did treat MMCs when the prefix was classical and its used implied a full word, e.g. photocopy as photo (graphic) copy. We also retained certain pseudo-compounds when the prefix was also a word that descended from the same root as the prefix, e.g. understand and over-whelmed.

A second routine in Automap called "Suggest N-Grams" was next employed to identify open compounds words in the text. The output of this routine contains a list of selected multi-word combinations which in our case consisted of $1511 \mathrm{n}$-grams. As above, both of the authors reviewed the list separately and later reconciled their selections. The result 
was a list of 79 open compounds such as bulletin board, dining room, parking lot and third world. With the addition of these n-grams the total number of unique MMCs rose to 395. Table 2 contains examples of each type of 11 relevant categories of MMCs appearing in the screenplay of Fight Club.

\section{Abstraction of Selected Words into Higher Order Conceptual Categories}

Abstraction is Diesner's (2012) second stage of a network text analysis. One of the most widely-employed methods of abstraction is stemming, i.e. the reducing of words to their stem, base, or root forms (Stemming, 2014). In this study, we used etymological stemming. Specifically, each morpheme in a multi-morphemic compound is assigned to a category defined as its etymological root. Where possible, that root is Indo-European, as defined in the American Heritage Dictionary of Indo-European Roots (Watkins, 2011). Because no software exists for etymological stemming, the mapping had to be done manually. As previously, both authors mapped all morphemes separately and then later reconciled our coding. At the conclusion of this process the $395 \mathrm{MMCs}$ were traced back to 384 unique etymological roots, $80 \%$ of which were Indo-European.

\section{Connecting the Concepts}

The third stage of a network text analysis involves establishing linking relationships between nodes. In the morphoetymological approach, a pair of nodes is deemed connected when they co-occur in the same MMC. As shown in Figure 2 , in our network the etymological roots wer-2 (to raise, lift, hold suspended) and pele-2 (flat; to spread) are connected because they co-occur in the compound airplane. Because the words plastic and floor also descend from the root pele2, then it is also connected to the Indo-European roots kae-id- ( ) and de- (to), and the Old English bagge, shown below as BAG. As shown in Figure 2, those nodes are connected by the multi-word expression floor-to-ceiling and the open compound plastic bag. Similarly, the words mid-air, airline, airway, and airport, link the root wer-2 to four other IndoEuropean roots - medhyo- ( ), lino- (line), wegh-2 (way, weight), and per-2 ( ). Among the 384 nodes in the network, there were 441 such connected pairs. Although that may seem like a lot, the number of possible pairs is 97020 and 441 represents only $0.45 \%$ of that number - a mere fraction. That number is so small because MMCs comprise only about $2 \%$ of the number of words in the document and because only MMCs can create such connections across nodes in the network when those nodes are etymological roots. One implication of the choice to focus in etymological relation ships is that many words that convey important information about the content of the story are necessarily excluded from the analysis.

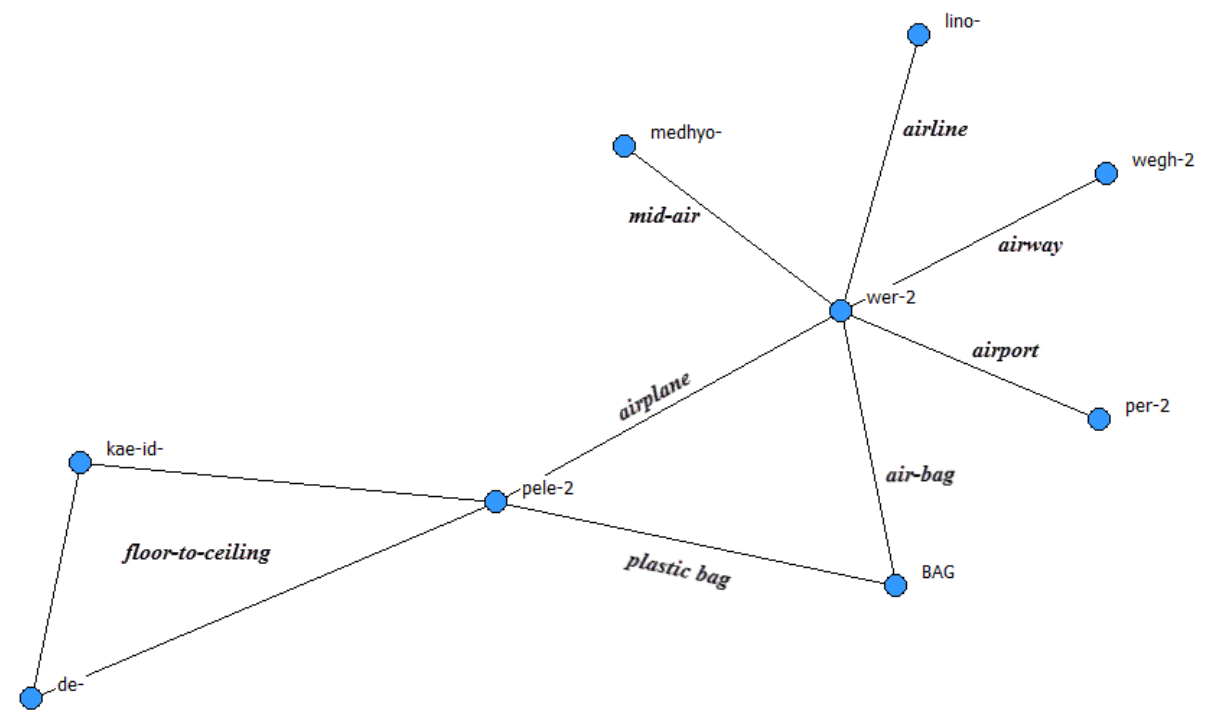

Figure 2. Sub-graph of the morpho-etymological text network for Fight Club

In social network analysis, the term "main component" is given to the largest portion of the network wherein all nodes are mutually reachable (Reachability, 2014). Of the 384 nodes in the text network for Fight Club, 296 were mutually-reachable. That is to say, there were one or more paths of varying lengths connecting every node (etymological root) to every other node. This network is presented in Fig. 3. 


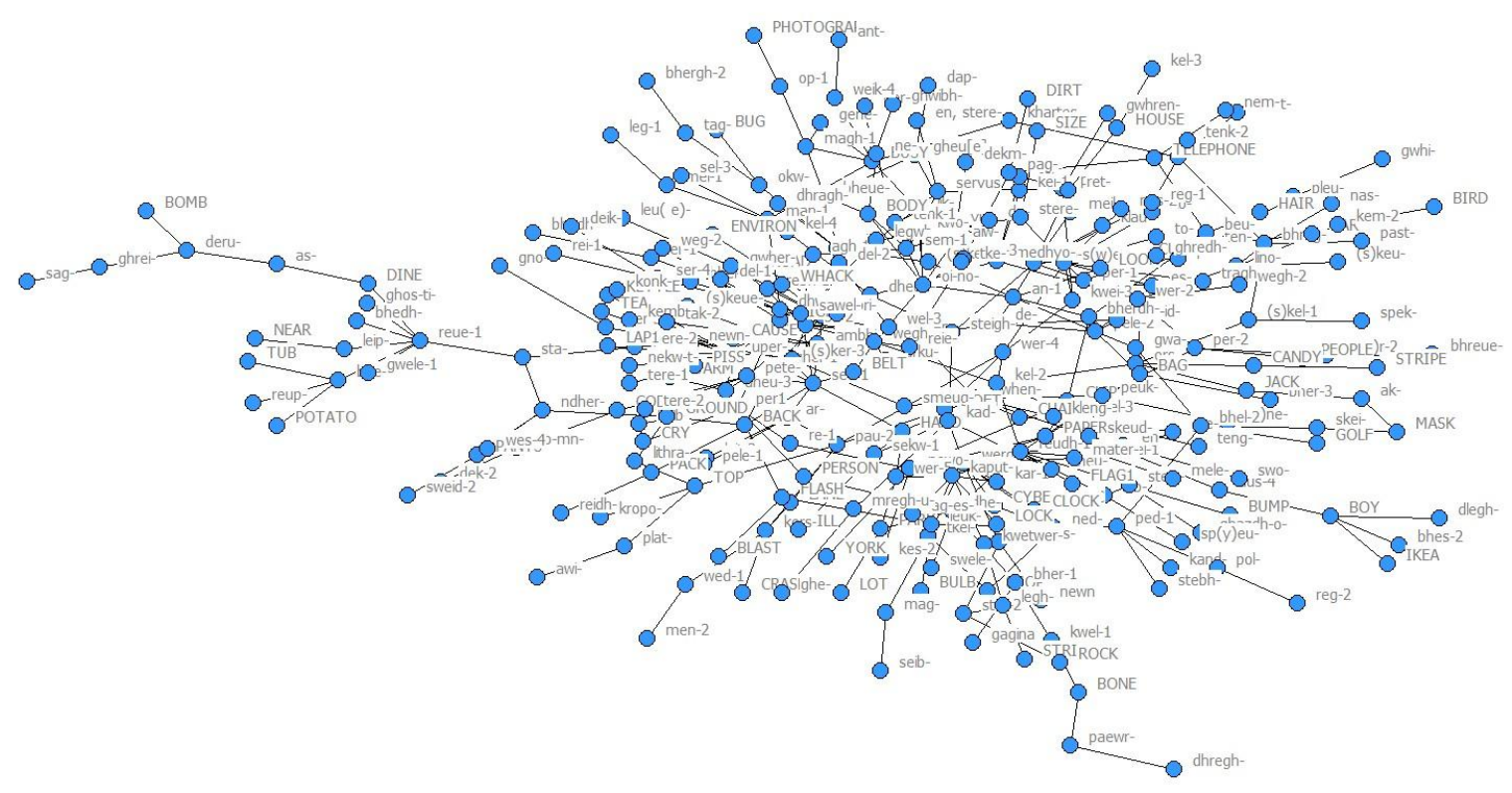

Figure 3. Main component of the morpho-etymological text network for Fight Club

\section{E. The Extraction of Meaning}

The last stage of a network text analysis involves the extraction of key themes from the text. As noted previously, this is typically accomplished through an analysis of the network's most influential nodes. In small networks this can often be done with visual inspection. But with 296 nodes and 387 ties, this network is quite clearly too large and complex to analyze visually. To further reduce the complexity we identified a subset of the most influential nodes among those in the main component. This was accomplished by calculating two measures of network influencedegree centrality and constraint. The first is simply a measure of the number of links that a node has in a network (Wasserman, 1994). The second is the degree to which a node links otherwise disconnected segments of a network. The measure of this propensity is called constraint, and the lower a node's constraint, the greater is its degree to serve as a connector between disparate sub-branches of a network (Burt, 2000). Fig. 3 below contains a reduced network of the one displayed in Fig. 2. It is comprised only of those 23 nodes that were in the top 10 in the whole network with regard to degree centrality and/or the bottom 10 with regard to constraint. The names and definitions of those nodes are displayed in Table III, along with examples of MMCs associated with those roots. The roots in the first column are order from the lowest to the highest value of constraint.

TABLE III.

SELECTED MULTI-MORPHEMIC COMPOUNDS ASSOCIATED WITH THE MOST CENTRAL

AND THE LEAST CONSTRAINED NODES IN THE MAIN COMPONENT OF THE TEXT NETWORK

AND THE LEAST CONSTRAINED NODES IN THE MAIN COMPONENT OF THE TEXT NETWORK
\begin{tabular}{|l|l|}
\hline Node (Definition) & Selected Multi-Morphemic Compounds \\
\hline s(w)e- (self) & self-destruction, self-improvement, security guard \\
\hline apo- (of, off) & show off, out-of-court settlement, \\
\hline ud- (out) & whacked-out, burnt-out, outrage \\
\hline werg- (to do; work) & Home Shopping Network, paperwork, sex organs, cyber-netting \\
\hline wegh- (way) & freeway, superhighway, runway \\
\hline uper- (over) & death-warmed-over, overnight, overturned \\
\hline se-2 (side) & sidelong, sidewalk, broadsides, passenger side \\
\hline sed-1 (seat) & out-of-court settlement, seat back, seatbelt \\
\hline oi-no- (one, unity) & everyone, anyone, someone \\
\hline upo- (up, over) & uppercut, upright, mixed-up, sit-ups \\
\hline reudh-1 (red) & lipstick red, red blood cell, red-and-blue, red-faced, red flags, redhead \\
\hline kaput- (head) & redhead, dickhead, headache, headlock, headquarters \\
\hline bysig- (busy) & businessman, business card, business trip, IBM, BusinessWeek \\
\hline an-1 (on) & onboard, one-on-one, onlookers \\
\hline sem-1 (some) & single-serving, something \\
\hline reue-1 (room) & stockroom, ballroom, hotel room, bedroom \\
\hline gwhen- (to strike, kill) & chain-link fence, gunshot, gunpoint, handgun \\
\hline dhwer- (door) & doorbell, doorframe, doorman, side door \\
\hline medhyo- (middle) & mid-air, middle-aged, mid-town \\
\hline wi- (with) & wide-eyed, goodbye (God be with you) \\
\hline hand (hand) & second hand, handkerchief \\
\hline wer-2 (to raise, lift) & airbag, airline, airplane, airport \\
\hline per1 (prime, first, for) & cry-for-help, first person, doorframe \\
\hline
\end{tabular}




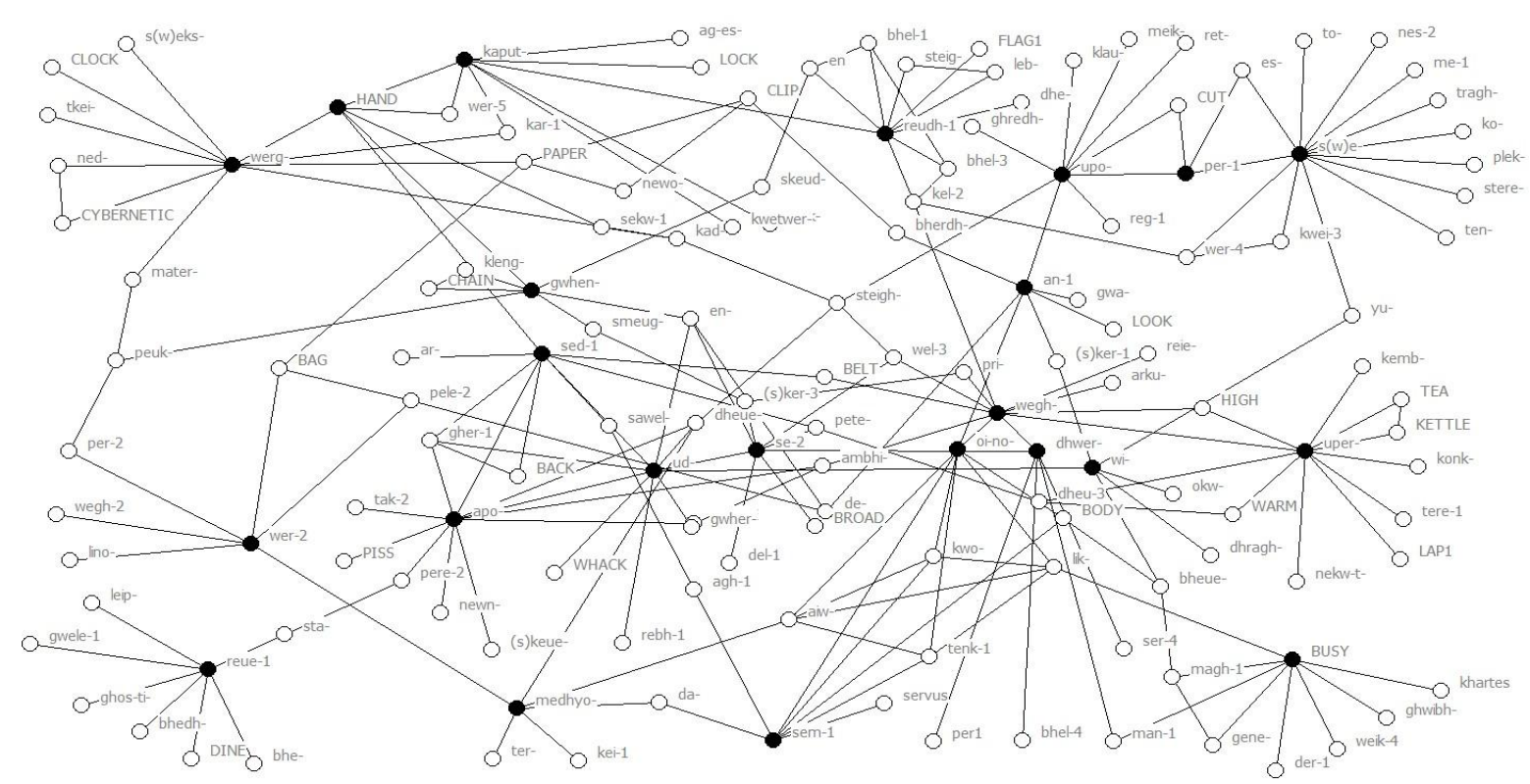

Figure 3. Morpho-Etymological Text Network Formed Only by the Most Central and the Least Constrained Nodes in the Main Component

\section{F. Comparing Findings}

Notably, the node with the both the lowest constraint score $(0.107)$ and highest degree centrality (15) is the IndoEuropean root $\mathbf{s}(\mathbf{w}) \mathbf{e}$ - which Watkins (2011, p. 90) defines as a " pronoun of the third person and reflexive (referring back to the subject of the sentence); further appearing in various forms referring to the social group as an entity." Words in the screenplay associated with this root include the reflexive pronouns myself, ourselves, itself, etc. as well as the words security guard, self-contained, self-destruction, self-employed, self-improvement, and self-portrait. Several other words descending from that root appear in the screenplay but are not part of MMCs. They are severed, secret, sure, unsure, solitaire, desolate, customer, and sullen. Other words descending from $\mathbf{s}(\mathbf{w}) \mathbf{e}-$ but not found in the screenplay are secure, sedition, separate, sever, sure, ethnic, idiot, solo, desolate, custom, sullen, and solitude. The meaning of this root, the words in the story directly tied to it, and the others that descend from it are clearly indicative IDENTITY-the second most influential theme identified in our prior analysis.

The Indo-European root werg- means "to do" (ibid, p. 103). It is one of two nodes with the third highest number of links (13). It and the root bysig - shown in the graph as "BUSY"- both have the fourth lowest constraint value (0.153). Words descending from werg- and appearing in the screenplay include Home Shopping Network, homework, network, organic matter, paper work, sex organs, case worker, clockwork, cyber-netting, handiwork, and hard-working. Two other words descending from this root appear in the text but not in the network-surgery, and boulevard. One other descendant of werg- that does not appear in the screenplay is ergonomics, a word that the MacMillan Dictionary defines as "the study of the way that furniture, equipment, etc. can be designed so that it is easy and comfortable to use and produces the most benefits and the best working or living conditions." This definition is noteworthy given the protagonist's admission that he had "become a slave to the Ikea nesting instinct," that he is depicted assembling Ikea furniture, and that his alter-ego Tyler mockingly refers to him as "Ikea-boy." Words associated with bysig- include $I B M$ (International Business Machines), business card, business trip, BusinessWeek, Business-like, businessman, and businesswoman. Clearly the bulk of these words relate to the third most influential theme identified earlier-CAPITAL.

Interestingly, none of the most central or least constrained nodes are strongly associated with the theme of GENDER. That is to say, none of their definitions are explicitly or implicitly gendered. Nor are any of the words that descend from them. In fact, we have to go to the $14^{\text {th }}$ least constrained and 12 most central node to find the IE root man-1 which means "man" (ibid, p. 52). Descending from that root are the words businessman, madman, doorman, salesman, and TFM (Task Force Man). Of these, only doorman and businessman appear in the reduced network formed by the top nodes. And there is also the word businesswoman which is associated with the root bysig-, as noted above. These three are hardly sufficient to say that the theme of GENDER - the most influential one identified above-is strongly emphasized in the text network. Notably, this conclusion has more support than there would appear at first glance. Although it is not easy to ascertain this from a visual examination of Fig. 1, fully 25 of the 52 journal articles-just short of half-made no mention whatsoever of gender related issues. Among those 25, the themes of IDENTITY and CAPITAL are the influential, followed very closely by ANARCHISM.

\section{CONCLUSION}

The objective of the preceding study was to determine whether network text analysis could be used from the topdown, i.e. to confirm or disconfirm independently-obtained information concerning the key themes in a text. That 
objective has been squarely met. We used 52 peer-reviewed journal articles about Fight Club to establish very clear, prior expectations about the themes that should be present in that text. The top three themes that we identified were GENDER, IDENTITY, and CAPITAL. Our network text analysis applied a novel approach-Hunter's (2014a) morpho-etymological method. The contribution of the present study stems from the fact that this method-like many similar ones - has previously only been applied using a bottom-up approach, i.e. to identify and extract themes from in a text rather than to verify them. The results of the analysis conducted herein found the expected relationship between themes and influential nodes. In particular, we found that the most influential node - as measured by degree centrality and constraint - was $\mathbf{s}(\mathbf{w}) \mathbf{e}-$ which essentially means "self" and which is associated with the reflexive pronouns, e.g. myself, as well as several hyphenated compounds like self-improvement and self-destruction. These multi-morphemic compounds (MMCs) clearly spoke to the second most important theme that we identified-IDENTITY. We also found that two other highly influential nodes — werg- (to do) and bysig (busy) — were associated with a number of MMCs that were consonant with the third most prominent theme-CAPITAL. Notably, we found that none of the most influential nodes and related MMCs emphasized the most prominent theme-GENDER. But that is not as disconfirming of the method as it appears. Even though GENDER was the dominant theme, it was not identified in all of the studies-just a little over half (27 of 52). The remaining 25 that did not identify GENDER had IDENTITY and CAPITAL tied for the most prominent theme while ANARCHISM was the most influential. This indicates something very important. It shows that the method has revealed a major fault line in the academic literature, one that sees the story through the lenses of gender roles, masculinity, paternalism, virility and feminization, and another which emphasizes anarchism, nihilism, post-modernism, and a dystopian ethos. In short, one sees a crisis of masculinity while another sees men in crisis. But cultural criticism is inherently subjective, and so network text analysis can't determine whether either of these perspectives is the correct one. What it can do-although we had not planned to do so-is show that differences exist even in the face of substantial agreement. What it allows is for an analyst to ascertain - in a quantitative and objective sense - what are the underlying dimensions of the field of study.

\section{ACKNOWLEDGEMENT}

The authors would like to thank Sham Kekre for providing funding to present an earlier version of this paper at the $34^{\text {th }}$ Sunbelt Conference of the International Network for Social Network Analysis in St. Petersburg Florida in February 2014. We'd also like to thank Patrick McGinnis, Patrick Sileo, Peter Stuettgen, John Gasper, George White, Tom Emerson, Steve Calabrese, Muhammad Farooqi, Steve Vargo, Ben Collier and two anonymous reviewers for helpful feedback on earlier drafts of this paper.

\section{APPENDIX. JOURNALS OF THE CORPUS}

1. Aparicio, J. (2013). Your Heart Is My Piñata: Chuck Palahniuk's Unconventional Love Stories. ANQ: A Quarterly Journal of Short Articles, Notes and Reviews, 26 (3), 210-5.

2. Baker, R. (2014). Chuck Palahniuk's Fight Club Apropos of Sartre's Bad Faith and Camus's Calculated Culpability. Global Journal of Human-Social Science Research, 14(1), 1-9.

3. Barker, J. (2008). A Hero Will Rise: The Myth of the Fascist Man in Fight Club and Gladiator. Literature/Film Quarterly, 36(3), 171-80.

4. Bedford, M. (2011). Smells like 1990s Spirit: The dazzling deception of Fight Club's grunge-aesthetic. New Cinemas: Journal of Contemporary Film, 9(1), 49-63.

5. Bishop, K. (2006). Artistic Schizophrenia: How Fight Club's Message Is Subverted by Its Own Nature. Studies in Popular Culture, 29(1), 41-56.

6. Boon, K. (2003). Men and Nostalgia for Violence: Culture and Culpability in Chuck Palahniuk's Fight Club. The Journal of Men's Studies, 11(3), 267-276.

7. Brookey, R. \& Westerfelhaus, R. (2002). Hiding homoeroticism in plain view: The Fight Club DVD as digital closet. Critical Studies in Media Communication, 19(1), 21-43.

8. Brown, W., \& Fleming, D. (2011). Deterritorialisation and Schizoanalysis in David Fincher's Fight Club. Deleuze Studies, 5(2), 275-299.

9. Burgess, O. (2012). Revolutionary Bodies in Chuck Palahniuk's Fight Club. Utopian Studies, 23(1), 263-280.

10. Clark, J. (2002). Faludi, Fight Club, and phallic masculinity: Exploring the emasculating economics of patriarchy. The Journal of Men's Studies, 11(1), 65-76.

11. Craine, J., \& Aitken, S. (2004). Street fighting: Placing the crisis of masculinity in David Fincher's Fight Club. GeoJournal, 59(4), 289-296.

12. Deacy, C. (2002). Integration and rebirth through confrontation: Fight Club and American Beauty as contemporary religious parables. Journal of Contemporary Religion, 7(1), 61-73.

13. Del Gizzo, S. (2008). The American Dream Unhinged: Romance and Reality in The Great Gatsby and Fight Club. The F. Scott Fitzgerald Review, 6(1), 69-94.

14. Diken, B., \& Laustsen, C. (2002). Enjoy Your Fight!-Fight Club as a Symptom of the Network Society. Cultural Values, 6(4), 349-367. 
15. Friday, K. (2003). A Generation of Men Without History: Fight Club, Masculinity, and the Historical Symptom. Postmodern Culture, 13(3), 1-12.

16. Giroux, H. (2001). Private Satisfactions and Public Disorders: Fight Club, Patriarchy, and the Politics of Masculine Violence. JAC Online, 24(1), 1-31.

17. Gold, S. N. (2004). Fight Club: A depiction of contemporary society as dissociogenic. Journal of Trauma \& Dissociation, 5(2), 13-34.

18. Gravett, S. (2002). Marla, Freud, Religion, and Manhood: An Interpretation of David Fincher's Fight Club. Journal of Religion and Popular Culture, 2(1), 14-24.

19. Gunn, J., \& Frentz, T. (2010). Fighting for father: Fight Club as cinematic psychosis. Western Journal of Communication, 74(3), 269-291.

20. Henderson, G. (2011). What was Fight Club? Theses on the value worlds of trash capitalism. Cultural Geographies, 18(2), 143-170.

21. Iocco, M. (2003). Whom do you fight? The limits and excesses of masculinity in Fight Club. M/C: A Journal of Media and Culture, 6(1), 1-7.

22. Iocco, M. (2007). Addicted to Affliction: Masculinity and Perversity in Crash and Fight Club. Gothic Studies, 9(1), 46-56.

23. Jordan, M. (2002). Marxism, Not Manhood Accommodation and Impasse in Seamus Heaney's Beowulf and Chuck Palahniuk's Fight Club. Men and Masculinities, 4(4), 368-379.

24. Kavadlo, J. (2005). The Fiction of Self-destruction: Chuck Palahniuk, Closet Moralist. Stirrings Still: The International Journal of Existential Literature, 2(2), 3-24.

25. Kennett, P. (2005). Fight Club and the Dangers of Oedipal Obsession. Stirrings Still: The International Journal of Existential Literature, 2(2), 48-64.

26. King, C. (2009). It cuts both ways: Fight Club, masculinity, and abject hegemony. Communication and Critical/Cultural Studies, 6(4), 366-385.

27. Kravitz, B. (2004). The Culture of Disease and The Dis-ease of Culture: Re-membering the Body in Fight Club and Memento. Studies in Popular Culture, 26(2), 29-48.

28. Kusz, K. (2002). Fight Club and the Art/Politics of White Male Victimization and Reflexive Sadomasochism. International Review for the Sociology of Sport, 37(3-4), 465-470.

29. Layton, L. (2011). Something to do with a girl named Marla Singer: Capitalism, narcissism, and therapeutic discourse in David Fincher's Fight Club. Free Associations, (62), 111-134.

30. Lindgren, S. (2011). A copy, of a copy, of a copy?: Exploring masculinity under transformation in Fight Club. Scope. An Online Journal of Film Studies, 19(1), 1-27.

31. Lizardo, O. (2007). Fight Club, or the cultural contradictions of late capitalism. Journal for Cultural Research, 11(3), 221-243.

32. Locke, B. (2014). The White Man's Bruce Lee: Race and the Construction of White Masculinity in David Fincher's Fight Club (1999). Journal of Asian American Studies, 17(1), 61-89.

33. Lockwood, R. (2008). Cults, Consumerism, and the Construction of Self: Exploring the Religious within Fight Club. Journal of Contemporary Religion, 23(3), 321-335.

34. McCullough, J. (2005). Tedium and torture: Fight Club, globalization and professionals in crisis. CineAction, 65, 44-54.

35. Mitchell, K. (2013). A Copy of a Copy of a Copy: Productive Repetition in Fight Club. Jeunesse: Young People, Texts, Cultures, 5(1), 108-131.

36. Morris, T. (2014). Networking vehement frames: neo-Nazi and violent jihadi demagoguery. Behavioral Sciences of Terrorism and Political Aggression, 6(3), 163-82.

37. Ng, A. (2005). Muscular Existentialism in Chuck Palahniuk's Fight Club. Stirrings Still: The International Journal of Existential Literature, 2(2), 116-38.

38. Palladino, P., \& Young, T. (2003). Fight Club and the World Trade Center: On Metaphor, Scale, and the Spatiotemporal (Dis) location of Violence. Journal for Cultural Research, 7(2), 195-218.

39. Pettus, M. (2000). Terminal simulation: Revolution in Chuck Palahniuk's Fight Club. Hungarian Journal of English and American Studies, 6(2), 111-127.

40. Reed, C. (2007). Fight Club: An Exploration of Buddhism. Journal of Religion \& Film, 11(2), 2-11.

41. Rehling, N. (2001). Fight Club Takes a Beating: Masculinity, Masochism and the Politics of Disavowal. Gramma: Journal of Theory and Criticism, 9, 187-205.

42. Robinson, S. (2011). Feminized Men and Inauthentic Women: Fight Club and the Limits of Anti-Consumerist Critique. Genders, 53, 1-33.

43. Ruddell, C. (2007). Virility and Vulnerability, Splitting and Masculinity in Fight Club: A Tale of Contemporary Male Identity Issues. Extrapolation, 48(3), 493-503.

44. Schultz, R. (2011). White Guys Who Prefer Not To: From Passive Resistance (Bartleby) To Terrorist Acts (Fight Club). The Journal of Popular Culture, 44(3), 583-605. 
45. Slade, A. (2011). To Live Like Fighting Cocks: Fight Club and the Ethics of Masculinity. Quarterly Review of Film and Video, 28(3), 230-238.

46. Spicer, A. (2001). Out of the cynical bind? A reflection on resistance in Fight Club. Ephemera, 1(1), 92-102.

47. Stirling, K. (2004). Dr. Jekyll and Mr. Jackass: Fight Club as a Refraction of Hogg's Justified Sinner and Stevenson's Dr. Jekyll and Mr. Hyde. Postmodern Studies, 35(1), 83-94.

48. Ta, L. (2006). Hurt so good: Fight Club, masculine violence, and the crisis of capitalism. The Journal of American Culture, 29(3), 265-277.

49. Tuss, A. (2004). Masculine identity and success: a critical analysis of Patricia Highsmith's The Talented Mr. Ripley and Chuck Palahniuk's Fight Club. The Journal of Men's Studies, 12(2), 93-102.

50. Vafa, A., \& Talif, R. (2011). Manhood in Crisis: Powerlessness, Homophobia and Violence in Fight Club. Pertanika Journal of Social Science and Humanities, 19(2), 449-457.

51. Westerfelhaus, R., \& Brookey, R. (2004). At the unlikely confluence of conservative religion and popular culture: Fight Club as heteronormative ritual. Text and Performance Quarterly, 24(3-4), 302-326.

52. Yeo, D. (2014). Gothic Paranoia in David Fincher's Seven, The Game and Fight Club. Aeternum: The Journal of Contemporary Gothic Studies, 1, 16-25.

\section{REFERENCES}

[1] Aparicio, J. (2013). Your Heart Is My Piñata: Chuck Palahniuk's Unconventional Love Stories. ANQ: A Quarterly Journal of Short Articles, Notes and Reviews, 26 (3), 210-5.

[2] Baker, R. (2014). Chuck Palahniuk's Fight Club Apropos of Sartre's Bad Faith and Camus's Calculated Culpability. Global Journal of Human-Social Science Research, 14(1), 1-9.

[3] Bakker, R. (1987). Knowledge Graphs: representation and structuring of scientific knowledge. Ph.D. Thesis. Dept. of Applied Mathematics, University of Twente, Netherlands.

[4] Barker, J. (2008). A Hero Will Rise: The Myth of the Fascist Man in Fight Club and Gladiator. Literature/Film Quarterly, 36(3), 171-80.

[5] Bedford, M. (2011). Smells like 1990s Spirit: The dazzling deception of Fight Club's grunge-aesthetic. New Cinemas: Journal of Contemporary Film, 9(1), 49-63.

[6] Bishop, K. (2006). Artistic Schizophrenia: How Fight Club's Message Is Subverted by Its Own Nature. Studies in Popular Culture, 29(1), 41-56.

[7] Boon, K. (2003). Men and Nostalgia for Violence: Culture and Culpability in Chuck Palahniuk's Fight Club. The Journal of Men's Studies, 11(3), 267-276.

[8] Box Office Mojo. Fight Club. http://www.boxofficemojo.com/movies/?id=fightclub.htm (accessed 27 September 2014).

[9] Brookey, R. \& Westerfelhaus, R. (2002). Hiding homoeroticism in plain view: The Fight Club DVD as digital closet. Critical Studies in Media Communication, 19(1), 21-43.

[10] Brown, W., \& Fleming, D. (2011). Deterritorialisation and Schizoanalysis in David Fincher's Fight Club. Deleuze Studies, 5(2), 275-299.

[11] Burgess, O. (2012). Revolutionary Bodies in Chuck Palahniuk's Fight Club. Utopian Studies, 23(1), 263-280.

[12] Burt, R. (2000). The network structure of social capital. Research in Organizational Behavior, 22, 345-423.

[13] Carley, K. (1997). Extracting team mental models through textual analysis. Journal of Organizational Behavior, 18.1, 533-558.

[14] Carley, K., \& Palmquist, M. (1992). Extracting, representing, and analyzing mental models. Social Forces, 70(3), 601-636.

[15] Carley, K., Columbus, D. \& Landwehr, P. (2013). AutoMap User's Guide 2013. Carnegie Mellon University, School of Computer Science, Institute for Software Research, Technical Report, CMU-ISR-13-105

[16] Chung, C., \& Park, H. (2010). Textual analysis of a political message: the inaugural addresses of two Korean presidents. Social Science Information,49(2), 215-239.

[17] Clark, J. (2002). Faludi, Fight Club, and phallic masculinity: Exploring the emasculating economics of patriarchy. The Journal of Men's Studies, 11(1), 65-76.

[18] Collins, A., \& Loftus, E. (1975). A spreading-activation theory of semantic processing. Psychological Review, 82(6), 407-28.

[19] Corman, S., Kuhn, T., McPhee, R., \& Dooley, K. (2002). Studying Complex Discursive Systems. Human Communication Research, 28(2), 157-206.

[20] Craine, J., \& Aitken, S. (2004). Street Fighting: Placing the crisis of masculinity in David Fincher's Fight Club. GeoJournal, 59(4), 289-296.

[21] Crowdus, G. (2000). Getting Exercised over Fight Club. Cineaste, 25(4), 46-8.

[22] Danowski, J. (1993). Network analysis of message content. Progress in Communication Sciences, 12, 198-221.

[23] Deacy, C. (2002). Integration and rebirth through confrontation: Fight Club and American Beauty as contemporary religious parables. Journal of Contemporary Religion, 7(1), 61-73.

[24] Del Gizzo, S. (2008). The American Dream Unhinged: Romance and Reality in The Great Gatsby and Fight Club. The F. Scott Fitzgerald Review, 6(1), 69-94.

[25] Diesner, J. (2012). Uncovering and managing the impact of methodological choices for the computational construction of socio-technical networks from texts. Carnegie-Mellon University, Software Research Institute.

[26] Diesner, J. (2013). From Texts to Networks: Detecting and Managing the Impact of Methodological Choices for Extracting Network Data from Text Data. KI-Künstliche Intelligenz, 27(1), 75-78.

[27] Diesner, J., \& Carley, K. (2005). Revealing social structure from texts: meta-matrix text analysis as a novel method for network text analysis. In V.K. Narayanan and Deborah J. Armstrong (eds.), Causal mapping for information systems and technology research: Approaches, advances, and illustrations. Hershey, PA: IGI Global, 81-108. 
[28] Diken, B., \& Laustsen, C. (2002). Enjoy Your Fight!-Fight Club as a Symptom of the Network Society. Cultural Values, 6(4), 349-367.

[29] Fischer-Starcke, B. (2009). Keywords and frequent phrases of Jane Austen's Pride and Prejudice A corpus-stylistic analysis. International Journal of Corpus Linguistics, 14(4), 492-523.

[30] Friday, K. (2003). A Generation of Men Without History: Fight Club, Masculinity, and the Historical Symptom. Postmodern Culture, 13(3), 1-12.

[31] Giroux, H. (2001). Private Satisfactions and Public Disorders: Fight Club, Patriarchy, and the Politics of Masculine Violence. JAC Online, 24(1), 1-31.

[32] Gold, S. (2004). Fight Club: A depiction of contemporary society as dissociogenic. Journal of Trauma \& Dissociation, 5(2), 13-34.

[33] Gravett, S. (2002). Marla, Freud, Religion, and Manhood: An Interpretation of David Fincher's Fight Club. Journal of Religion and Popular Culture, 2(1), 14-24.

[34] Grbic, D., Hafferty, F., \& Hafferty, P. (2013). Medical school mission statements as reflections of institutional identity and educational purpose: A network text analysis. Academic Medicine, 88(6), 852-860.

[35] Gunn, J., \& Frentz, T. (2010). Fighting for father: Fight Club as cinematic psychosis. Western Journal of Communication, 74(3), 269-291.

[36] Henderson, G. (2011). What was Fight Club? Theses on the value worlds of trash capitalism. Cultural Geographies, 18(2), 143-170.

[37] Hunter, S. (2014a). A Novel Method of Network Text Analysis. Open Journal of Modern Linguistics, 4(02), 350-66.

[38] Hunter, S. (2014b). A Semi-Automated Method of Network Text Analysis Applied to 150 Original Screenplays. Proceedings of the Joint Workshop on Social Dynamics and Personal Attributes in Social Media. 1(1), 68-76.

[39] Hunter, S., \& Smith, S. (2013). Thematic and Lexical Repetition in a Contemporary Screenplay. Open Journal of Modern Linguistics, 3(1), 9-19.

[40] Iocco, M. (2003). Whom do you fight? The limits and excesses of masculinity in Fight Club. M/C: A Journal of Media and Culture, 6(1), 1-7.

[41] Iocco, M. (2007). Addicted to Affliction: Masculinity and Perversity in Crash and Fight Club. Gothic Studies, 9(1), 46-56.

[42] Jordan, M. (2002). Marxism, Not Manhood Accommodation and Impasse in Seamus Heaney's Beowulf and Chuck Palahniuk's Fight Club. Men and Masculinities, 4(4), 368-379.

[43] Kavadlo, J. (2005). The Fiction of Self-destruction: Chuck Palahniuk, Closet Moralist. Stirrings Still: The International Journal of Existential Literature, 2(2), 3-24.

[44] Kennett, P. (2005). Fight Club and the Dangers of Oedipal Obsession. Stirrings Still: The International Journal of Existential Literature, 2(2), 48-64.

[45] King, C. (2009). It Cuts Both Ways: Fight Club, Masculinity, and Abject Hegemony. Communication and Critical/Cultural Studies, 6(4), 366-385.

[46] Kravitz, B. (2004). The Culture of Disease and The Dis-ease of Culture: Re-membering the Body in Fight Club and Memento. Studies in Popular Culture, 26(2), 29-48.

[47] Kusz, K. (2002). Fight Club and the Art/Politics of White Male Victimization and Reflexive Sadomasochism. International Review for the Sociology of Sport, 37(3-4), 465-470.

[48] Layton, L. (2011). Something to do with a girl named Marla Singer: Capitalism, narcissism, and therapeutic discourse in David Fincher's Fight Club. Free Associations, (62), 111-134.

[49] Light, R. (2014). From Words to Networks and Back: Digital Text, Computational Social Science, and the Case of Presidential Inaugural Addresses. Social Currents, 1(2), 111-29.

[50] Lindgren, S. (2011). A copy, of a copy, of a copy?: exploring masculinity under transformation in Fight Club. Scope. An online Journal of Film Studies, 19(1), 1-27.

[51] Lizardo, O. (2007). Fight Club, or the cultural contradictions of late capitalism. Journal for Cultural Research, 11(3), $221-243$.

[52] Locke, B. (2014). The White Man's Bruce Lee: Race and the Construction of White Masculinity in David Fincher's Fight Club (1999). Journal of Asian American Studies, 17(1), 61-89.

[53] Lockwood, R. (2008). Cults, Consumerism, and the Construction of Self: Exploring the Religious within Fight Club. Journal of Contemporary Religion, 23(3), 321-335.

[54] McCullough, J. (2005). Tedium and torture: Fight Club, globalization and professionals in crisis. CineAction, 65, 44-54.

[55] Mitchell, K. (2013). A Copy of a Copy of a Copy: Productive Repetition in Fight Club. Jeunesse: Young People, Texts, Cultures, 5(1), 108-131.

[56] Morris, T. (2014). Networking vehement frames: neo-Nazi and violent jihadi demagoguery. Behavioral Sciences of Terrorism and Political Aggression, 6(3), 163-82.

[57] Ng, A. (2005). Muscular Existentialism in Chuck Palahniuk's Fight Club. Stirrings Still: The International Journal of Existential Literature, 2(2), 116-38.

[58] Novak, J. (1990). Concept mapping: A useful tool for science education. Journal of Research in Science Teaching, 27(10), 937949.

[59] Palahniuk, C. (1996). Fight Club: A novel. WW Norton \& Company, New York.

[60] Palladino, P., \& Young, T. (2003). Fight Club and the World Trade Center: On Metaphor, Scale, and the Spatio-temporal (Dis) location of Violence. Journal for Cultural Research, 7(2), 195-218.

[61] Pettus, M. (2000). Terminal simulation: Revolution in Chuck Palahniuk's Fight Club. Hungarian Journal of English and American Studies, 6(2), 111-127.

[62] Popping, R. (2000). Computer-assisted text analysis. Sage, Thousand Oaks, CA.

[63] Popping, R., \& Roberts, C. W. (1997). Network approaches in text analysis. Springer Berlin, Heidelberg.

[64] Reachability. (2014). http://en.wikipedia.org/wiki/Reachability (accessed 22/09/2014)

[65] Reed, C. (2007). Fight Club: An Exploration of Buddhism. Journal of Religion \& Film, 11(2), 2-11. 
[66] Rehling, N. (2001). Fight Club Takes a Beating: Masculinity, Masochism and the Politics of Disavowal. Gramma: Journal of Theory and Criticism, 9, 187-205.

[67] Roberts, C. (1997). Text analysis for the social sciences: Methods for drawing statistical inferences from texts and transcripts. Hillsdale, NJ: Lawrence Erlbaum Associates.

[68] Robinson, S. (2011). Feminized Men and Inauthentic Women: Fight Club and the Limits of Anti-Consumerist Critique. Genders, 53, 1-33.

[69] Ruddell, C. (2007). Virility and Vulnerability, Splitting and Masculinity in Fight Club: A Tale of Contemporary Male Identity Issues. Extrapolation, 48(3), 493-503.

[70] Schultz, R. (2011). White Guys Who Prefer Not To: From Passive Resistance (Bartleby) To Terrorist Acts (Fight Club). The Journal of Popular Culture, 44(3), 583-605.

[71] Slade, A. (2011). To Live Like Fighting Cocks: Fight Club and the Ethics of Masculinity. Quarterly Review of Film and Video, 28(3), 230-238

[72] Smith, G. (1999). Inside Out: Gavin Smith Goes One-on-One with David Fincher. Film Comment, 35(5), 58-68.

[73] Sowa, J. (1992). Conceptual graphs as a universal knowledge representation. Computers \& Mathematics with Applications, 23(2), 75-93.

[74] Spicer, A. (2001). Out of the cynical bind? A reflection on resistance in Fight Club. Ephemera, 1(1), 92-102.

[75] Stemming. (2014). http://en.wikipedia.org/wiki/Stemming (accessed 26/09/2014).

[76] Stirling, K. (2004). Dr. Jekyll and Mr. Jackass: Fight Club as a Refraction of Hogg's Justified Sinner and Stevenson's Dr. Jekyll and Mr. Hyde. Postmodern Studies, 35(1), 83-94.

[77] Stubbs, M. (2005). Conrad in the computer: examples of quantitative stylistic methods. Language and Literature, 14(1), 5-24.

[78] Ta, L. (2006). Hurt so good: Fight Club, masculine violence, and the crisis of capitalism. The Journal of American Culture, 29(3), 265-277.

[79] Tambayong, L., \& Carley, K. (2012). Network Text Analysis in Computer-Intensive Rapid Ethnography Retrieval: An Example from Political Networks of Sudan. Journal of Social Structure, 13 (2), 1-24.

[80] Tuss, A. (2004). Masculine identity and success: a critical analysis of Patricia Highsmith's The talented Mr. Ripley and Chuck Palahniuk's Fight Club. The Journal of Men's Studies, 12(2), 93-102.

[81] Uhls, J., \& Palahniuk, C. (2000). Fight Club: The Original Screenplay. Los Angeles: ScreenPress.

[82] Vafa, A., \& Talif, R. (2011). Manhood in Crisis: Powerlessness, Homophobia and Violence in Fight Club. Pertanika Journal of Social Science and Humanities, 19(2), 449-457.

[83] van Atteveldt, W., Kleinnijenhuis, J., \& Ruigrok, N. (2008). Parsing, semantic networks, and political authority using syntactic analysis to extract semantic relations from Dutch newspaper articles. Political Analysis, 16(4), 428-446.

[84] Wasserman, S. (1994). Social Network Analysis: Methods and Applications (vol. 8). Cambridge, UK: Cambridge University Press.

[85] Watkins, C. (ed.) (2011). The American Heritage Dictionary of Indo-European Roots (3rd Ed). Boston: Houghton Mifflin Harcourt.

[86] Westerfelhaus, R., \& Brookey, R. (2004). At the unlikely confluence of conservative religion and popular culture: Fight Club as heteronormative ritual. Text and Performance Quarterly, 24(3-4), 302-326.

[87] Yeo, D. (2014). Gothic Paranoia in David Fincher's Seven, The Game and Fight Club. Aeternum: The Journal of Contemporary Gothic Studies, 1, 16-25.

Starling Hunter was born in California, USA, in 1963. He received his PhD in Organization Theory from Duke University in 1999. He is current an Associate Teaching Professor at Carnegie Mellon University's Tepper School of Business in Doha, Qatar. His research interests include organizational and text network analysis.

Saba Singh was born in New Dehli, India in 1991. In 2014 she received her Bachelors of Science in Business Administration with a major in marketing from the Tepper School of Business at Carnegie Mellon University in Doha, Qatar. She is currently employed as a business coordinator at the 60Degrees Creative Advertising Agency in Doha, Qatar. 